\title{
Shorter blooms expected with longer warm periods under climate change: an example from a shallow meso- eutrophic Mediterranean lake
}

\author{
Gary Free 1 - Mariano Bresciani $\cdot$ Monica Pinardi $\cdot$ Steef Peters $\cdot$ \\ Marnix Laanen $\cdot$ Rosalba Padula $\cdot$ Alessandra Cingolani $\cdot$ Fedra Charavgis • \\ Claudia Giardino
}

Received: 20 May 2021 / Revised: 20 October 2021 / Accepted: 20 November 2021 / Published online: 9 January 2022

(C) The Author(s) 2021

\begin{abstract}
Satellite data from the Climate Change Initiative (CCI) lakes project were used to examine the influence of climate on chlorophyll-a (Chl-a). Nonparametric multiplicative regression and machine learning were used to explain Chl-a concentration trend and dynamics. The main parameters of importance were seasonality, interannual variation, lake level, water temperature, the North Atlantic Oscillation, and antecedent rainfall. No evidence was found for an earlier onset of the summer phytoplankton
\end{abstract}

Guest editors: José L. Attayde, Renata F. Panosso, Vanessa Becker, Juliana D. Dias \& Erik Jeppesen / Advances in the Ecology of Shallow Lakes

G. Free $(\bowtie) \cdot$ M. Bresciani · M. Pinardi · C. Giardino Institute for Electromagnetic Sensing of the Environment, National Research Council, Via Bassini 15, 20133 Milan, Italy

e-mail: free.g@irea.cnr.it

M. Bresciani

e-mail: bresciani.m@irea.cnr.it

M. Pinardi

e-mail: pinardi.m@irea.cnr.it

C. Giardino

e-mail: giardino.c@irea.cnr.it

S. Peters - M. Laanen

Water Insight, Marijkeweg 22, 6709 PG Wageningen, The

Netherlands

e-mail: peters@waterinsight.nl

M. Laanen

e-mail: laanen@waterinsight.nl bloom related to the earlier onset of warmer temperatures. Instead, a curvilinear relationship between Chla and the temperature length of season above $20^{\circ} \mathrm{C}$ (LOS) was found with longer periods of warmer temperature leading to blooms of shorter duration. We suggest that a longer period of warmer temperatures in the summer may result in earlier uptake of nutrients or increased calcite precipitation resulting in a shortening of the duration of phytoplankton blooms. The current scenario of increasing LOS of temperature with climate change may lead to an alteration of phytoplankton phenological cycles resulting in blooms of shorter duration in lakes where nutrients become

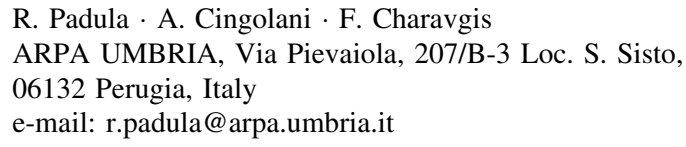

A. Cingolani

e-mail: a.cingolani@arpa.umbria.it

F. Charavgis

e-mail: f.charavgis@arpa.umbria.it 
limiting. Satellite-derived information on lake temperature and Chl-a concentration proved essential in detecting trends at appropriate resolution over time.

Keywords Shallow lakes - Cyanobacteria · Chlorophyll-a $\cdot$ Climate change $\cdot$ Remote sensing

\section{Introduction}

Shallow lakes have been identified as providing up to 39 essential ecosystem services globally such as drinking water, biodiversity, and recreational use which can be linked to sustainable development goals (Janssen et al., 2021). Anthropogenic pressure can cause a shift in state from being dominated by macrophytes to phytoplankton with a resulting loss in ecological functioning and degraded ecosystem services (Scheffer, 1989; Scheffer \& van Nes, 2007; Janssen et al., 2021). The abundance of phytoplankton is a key component used in assessments of trophic state and ecological quality of lakes (Council of the European Communities, 2000; Phillips et al., 2013). Some phytoplankton species, such as cyanobacteria, can form blooms or scum and can potentially produce toxins (cyanotoxins) that can have adverse effects on aquatic ecosystems and human health (Codd et al., 2005; Jöhnk et al., 2008; Ma et al., 2015). Physical and chemical parameters as well as seasonality affect phytoplankton distribution, abundance, and species diversity (Raymond, 1983; Ezra \& Nwankwo, 2001). For example, cyanobacteria are typically more abundant in nutrient-rich freshwater and are regulated by seasonal drivers, such as warmer temperatures and calmer weather which influence water column thermal stratification (Reynolds, 2006). In large shallow lakes which are polymictic (lack stratification), calm warm weather and directional light wind can be associated with surface accumulations of phytoplankton as well as promoting nutrient increase through internal loading that can further fuel blooms following storms (Søndergaard et al., 2003; Shi et al., 2017; Bresciani et al., 2020; Free et al., 2021b).

Climate change has an important influence on global biodiversity in lakes and has been listed as the third most important driver after invasive species and land-use change (Sala et al., 2000). The global increase in surface temperature in lakes in summer has been estimated as $0.34^{\circ} \mathrm{C}$ per decade but the influence of lake specific parameters like morphology frequently result in a lack of regional consistency to these trends (O'Reilly et al., 2015). Recent projections have indicated that lakes are predicted to get warmer for longer periods, with heatwaves potentially extending across multiple seasons (Woolway et al., 2021). Climate has been found to alter the seasonal pattern of phytoplankton in several ways, for example, through altering the physical environment with warmer winters reducing the incidence of stratification overturn and thereby altering nutrient cycling (Rogora et al., 2018; Free et al., 2021a). Whereas in high latitude lakes an increase in the length of growing season of phytoplankton has been attributed to an increasing proportion of rain relative to snow resulting in earlier delivery of nutrient loads to lakes (Maeda et al., 2019). For cyanobacteria, warmer temperatures have been found to result in the earlier occurrence of the growing season of Microsystis (Deng et al., 2014). Extreme increases in rainfall followed by warmer winter temperatures can combine to increase external and internal loading leading to earlier blooms of increased duration and extent (Qin et al., 2021). Warmer temperatures resulting from climate change have been predicted to lead to an increase in cyanobacteria through direct growth and also by promoting a stable water column under which buoyant cyanobacteria have a competitive advantage (Jöhnk et al., 2008). Future scenarios have predicted an increase in the intensity and frequency of cyanobacteria blooms resulting from warmer temperatures and eutrophication (Paerl \& Huisman, 2009; O’Neil et al., 2012; Huisman et al., 2018).

Satellite remote sensing can enable the observation of a suite of indicators of water quality and ecosystem condition for the study of long-term environmental trends in lakes (Tyler et al., 2016; Free et al., 2020) and supports different studies on the consequences of climate change on algal blooms (Qin et al., 2019; Shi et al., 2019). Phytoplankton is one the most frequently studied parameters with chlorophyll-a (Chl-a) often used as a proxy of phytoplankton biomass. The spatial coverage and temporal sampling frequency achievable with satellite images allow novel insights into phytoplankton dynamic processes in lakes (Ho et al., 2019), especially when paired with high-frequency groundbased measurements (Bresciani et al., 2020) that cannot be easily captured through in situ sampling 
(Palmer et al., 2015). Remote sensing has therefore been identified as a key component of future highlevel lake water quality management strategies (Carvalho et al., 2019).

Here we examine a 16-year (2003-2018) time series for a shallow lake (Trasimeno) in central Italy in order to identify changes in Chl-a concentration trend and dynamics in the context of climate change. Satellite observations of Chl-a provide higher temporal resolution in addition to their capacity to integrate signals over a large spatial area of the lake. We expect that warmer summers should increase the intensity and duration of summer blooms in the lake in line with climate change predictions.

\section{Materials and methods}

Study area

This study focuses on Lake Trasimeno, a posttectonic, shallow lake (maximum depth $6.3 \mathrm{~m}$ ), situated at an altitude of $258 \mathrm{~m}$ in central Italy $\left(43^{\circ} 08^{\prime} \mathrm{N}\right.$; $12^{\circ} 06^{\prime} \mathrm{E}$; Fig. 1). It is the fourth largest lake in the country (surface area $120.5 \mathrm{~km}^{2}$ ) and has a circular shape (Ludovisi \& Gaino, 2010). The catchment area (excluding the lake) is $264.5 \mathrm{~km}^{2}$ and given the small catchment area relative to that of the lake, the annual input of water can be lower than that lost through evaporation with a residence time highly dependent on rainfall with estimates ranging from $>4$ to $>20$ years (Jørgensen et al., 2007; Frondini et al., 2019). Therefore, the water balance of the lake is strongly dependent on rainfall which is typically $700 \mathrm{~mm}-$ just sufficient to keep the lake level stable, and with no significant outflow the lake can be classified as endorheic (Dragoni, 2004; Frondini et al., 2019). Land cover as a percentage of total catchment area (i.e., lake plus its catchment) was estimated as water (39.1), agricultural—mostly dominated by arable (30.9), forest (22.3), baren land (4.9), and urban (2.9) (Giardino et al., 2010). Lake Trasimeno is of considerable conservation importance, being part of the largest Natural Regional Park in peninsular Italy, a Site of Community Interest, a Special Protection Zone and contains two Natura 2000 sites (IT5210018 and IT5210070). Lake Trasimeno is generally turbid (average Secchi disk depth $0.9 \mathrm{~m}$ ) with an annual average total phosphorus concentration of $27 \mu \mathrm{g} \mathrm{l}^{-1}$ for the years 2015-2017, while the annual average of Chl-a ranged from 5.37 to $14.73 \mathrm{mg} \mathrm{m}^{-3}$ for this period (Cingolani \& Charavgis, 2018). This can be compared with the background reference concentrations of Chl-a assigned in legislation of $3.3 \mathrm{mg} \mathrm{m}^{-3}$ (DM, 2010). The values for Chl-a and TP would place the lake at the mesotrophic-eutrophic boundary according to the OECD trophic classification system, with TP not significantly changing since the 1970s (OECD, 1982; Ludovisi \& Gaino, 2010). Average alkalinity for the years 2015-2017 was $191 \mathrm{mg} \mathrm{l}^{-1}$ $\mathrm{CaCO}_{3}$. The water column is unstratified, with recurrent sediment resuspension due to wind action. According to the Water Framework Directive (WFD) system of classification, the lake is currently classified at moderate ecological status (Council of the European Communities, 2000, 2013; Cingolani \& Charavgis, 2017, 2018). Lake Trasimeno has a phytoplankton assemblage dominated by chlorophytes and dinoflagellates. Cryptophytes can also comprise a relatively large portion of the biomass, whereas euglenophytes and diatoms are relatively scarce (Havens et al., 2009). In summer, the high nutrient availability favors the occurrence of phytoplankton blooms, including cyanobacteria species (e.g., Cylindrospermopsis raciborskii, Planktothrix agardhii) (Havens et al., 2009; Charavgis et al., 2020).

\section{WISPstation in situ data}

The WISPstation (Peters et al., 2018) is a fixed position, above water autonomous spectroradiometer. It was installed on April 24th, 2018, 400 m north of Polvese island in Lake Trasimeno (Fig. 1) and collects remote sensing reflectance (Rrs) data every $15 \mathrm{~min}$. It measures the radiance and irradiance in the spectral range of 350-900 nm with a spectral resolution of $4.6 \mathrm{~nm}$ (full width at half maximum). The system is calibrated relative to a reference instrument (calibrated in a certified laboratory using a lamp and integrating sphere with National Institute of Standards and Technology traceable calibrations). The WISPstation is watertight and built into a highly climateresistant case. Temperature of the sensor and humidity in the case are registered with every measurement. Data are automatically sent using $3 \mathrm{G}$ connectivity to the database (WISPcloud). The instrument can be remotely accessed and, e.g., updated or configured to a specific time interval or measurement frequency. It is 


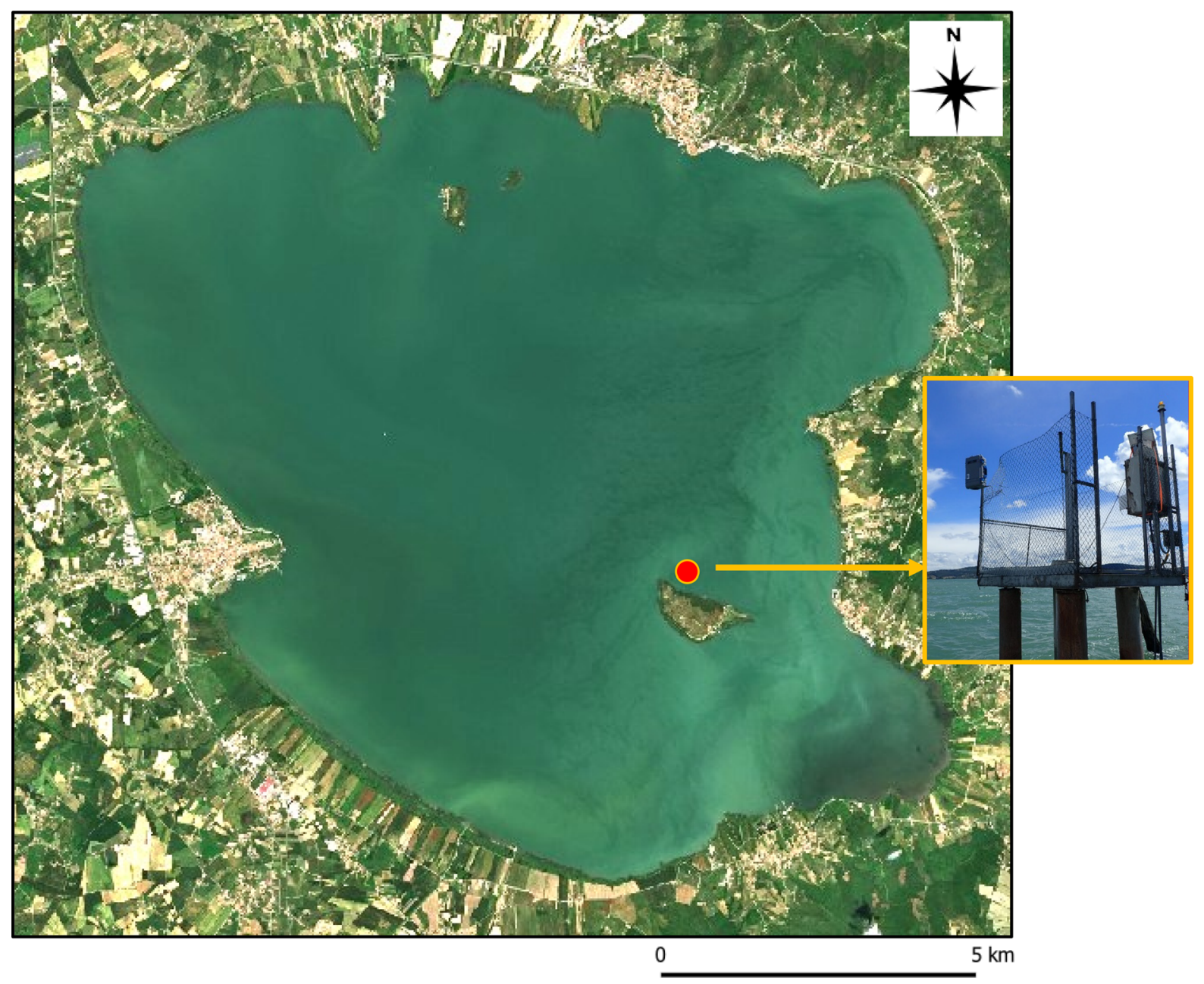

Fig. 1 True color composition of Lake Trasimeno from satellite (Sentinel-2 acquired on 5 June 2019) together with the WISPstation position (red dot)

autonomously powered by a solar panel and internal large battery. Its hyperspectral features allow a simulation of the band setting of satellite data and hence provides valuable reference data. For water quality monitoring purposes, the remote sensing reflectance observations are run through standard water quality algorithms to make a first estimate of Chl-a (Gons, 1999). The WISPstation-derived data of Chl-a concentrations were validated against values measured in water samples analyzed by ARPA Umbria (Bresciani et al., 2020). The WISPstation also enables estimates of the concentration of phycocyanin using specific algorithms (Simis, 2006). A subset of the data from July 1st until September 30th, 2019, was used for analysis.

\section{Long-term EO dataset}

The European Space Agency's Climate Change Initiative (CCI) aims to exploit the long-term global Earth Observation record to produce Essential Climate Variables (ECVs) supporting the United Nations Framework Convention on Climate Change (UNFCCC). The objective of the CCI dataset for the ECV Lakes is to use satellite Earth Observation data to create the largest and longest possible consistent, open global record of five lake thematic variables: lake water level, lake area extent, temperature, waterleaving reflectance, and ice cover. The main characteristics of this dataset (Crétaux et al., 2020) are as follows: 
- Spatial coverage: 250 globally distributed lakes, set to expand to around 2000 in the second phase

- Spatial resolution: $1 / 120^{\circ}$ global grid

- Temporal resolution: daily netCDF files containing all thematic variables including uncertainty

- Temporal coverage: from 1992 up to 2019.

For Lake Trasimeno, lake surface water temperature (LSWT) and Chl-a (derived from water-leaving reflectance data from MERIS and OLCI sensors) were extracted from the CCI Lakes database version 1.0. Quality level 4 and 5 were used to filter temperature values; these represent the level of confidence that the LSWT is valid and are classified as suitable for climate applications, similarly only a Chl-a uncertainty below $60 \%$ was used for analysis (Simis et al., 2020). The dataset for LSWT dates from 1993 while that for Chl-a starts in 2002. A total of 24 satellites were used to compile data in the CCI Lakes project and are listed in the product user guide (Simis et al., 2020). The CCI dataset presents an opportunity to examine what parameters are important in controlling the size of phytoplankton blooms and their interannual variation and phenology. There is a significant data gap in Chl-a from 2012 to 2015 when optical satellite data with the same characteristics (i.e., MERIS and OLCI) were not available, while other approaches, e.g., Huang et al. (2019) who used MODIS for long-term mapping of phytoplankton in Lake Taihu, were not yet considered suitable for Lake Trasimeno. In addition, gaps are also present due to satellite overpass limitations, where images were contaminated by cloud cover or where marked invalid for analysis (Simis et al., 2020). One of the objectives of the work was to test the ECV Lakes dataset, exploring potential for scientific research and also the current limitations of the dataset.

Few in situ environmental datasets are available to match this temporal resolution so daily climatic data were obtained from ERA5, the fifth generation of the European Centre for Medium-Range Weather Forecasts (ECMWF) reanalysis for the global climate and weather (https://cds.climate.copernicus.eu/cdsapp\#!/ home). Data used for analysis included the following: wind vectors to represent speed and direction, $2 \mathrm{~m}$ air temperature (temperature of air at $2 \mathrm{~m}$ above the surface), total precipitation, and the sum of rainfall for the preceding seven days. Lake level at S. Savino station (Magione village) was obtained from the regional authority (Umbrian Regional Hydrographic
Service. Available online: https://annali.regione. umbria.it/\# (accessed on 15 March 2021). Several studies have detected changes in Italian lakes linked to long-term climate change and fluctuations in large scale regional climate drivers such as the North Atlantic Oscillation index (NAO) and the East Atlantic pattern (EA) during winter (Rogora et al., 2018; Salmaso et al., 2018). Daily values of the North Atlantic Oscillation (NAO) were obtained from NOAA-CPC (https://www.cpc.ncep.noaa.gov/ products/precip/CWlink/pna/nao.shtml).

Analysis

For the analysis, two approaches were trialedGoogle AI (Artificial Intelligence) and Nonparametric Multiplicative Regression (NPMR). NPMR (McCune, 2006) was used to estimate the response of average daily Chl-a concentration to climate and environmental parameters listed above. NPMR can define response surfaces using predictors in a multiplicative rather than in an additive way. This method is progressive in better defining unimodal responses than other methods such as multiple regression (McCune, 2006). It has previously been applied to model tree species distribution (Yost, 2008), the response of lichens to climate change (Ellis et al., 2007), and in time-series analysis (Nicolaou \& Constandinou, 2016). NPMR was applied using the software HyperNiche version 2.3 (McCune \& Mefford, 2009). The response of Chl-a was estimated using a local mean multiplicative smoothing function with Gaussian weighting. NPMR models were produced by adding predictors stepwise with fit expressed as a cross-validated $R^{2}\left(x R^{2}\right)$ which can be interpreted in a similar way as a measure of fit as a traditional $R^{2}$. The sensitivity, a measure of influence of each parameter included in the NPMR model, was estimated by altering the range of predictors by \pm 0.05 (i.e., 5\%) with resulting deviations scaled as a proportion of the observed range of the response variable. Sensitivity can be used to evaluate the relative importance of variables included in models because NPMR models are unlike linear regression and have no fixed coefficients or slopes. Google AI AutoML was also used to develop a model for Chl-a as a designated feature. The supervised learning model followed a regression approach with chronological assignment using the first $80 \%$ of the time series for 
model training with each subsequent $10 \%$ used for validation (a tuning of the models hyper parameters) and testing (independent data used to derive the model's performance statistics) (https://cloud.google. com/automl-tables). For AI and NPMR analysis, the Chl-a concentration and lake surface water temperature were linear-interpolated to daily values using the temporal smoothing and gap filling (tsgf) linear function in the $\mathrm{R}$ package greenbrown (Forkel \& Wutzler, 2015; R Core Team, 2019). Theil-Sen estimates for slope of air temperature were carried out in the openair package in R (Carslaw \& Ropkins, 2012). Speakman rank (rS) correlation was calculated using DataDesk (Velleman, 1989).

For phenological analysis, calculation of the start of season (SOS), end of season (EOS), and length of season (LOS), a spline interpolation was used as this smoothed the seasonal patterns. Interpolation and smoothing is a standard and essential step in phenological analysis in order to identify the timing of seasonal change and this technique has been used to determine the changes in land cover phenology (Forkel et al., 2013, 2015; García et al., 2019). For phenological analysis, we used $15 \mathrm{mg} \mathrm{m}^{-3}$ of Chl-a as a level that could be considered as a starting point for the summer bloom for Lake Trasimeno, and this concentration has been used as a trigger value for instigating enhanced bloom monitoring (Touchette et al., 2007). We calculated the SOS as the day of year when the Chl-a concentration first reached $15 \mathrm{mg} \mathrm{m}^{3}$ and the EOS when it subsequently declined below $15 \mathrm{mg} \mathrm{m}^{3}$. The LOS was the difference between the two values. For comparison with LSWT, we followed the same approach using $20^{\circ} \mathrm{C}$ to define SOS, EOS, and LOS. This temperature was selected as the optima for many cyanobacteria have been considered above $20^{\circ} \mathrm{C}$ (Konopka \& Brock, 1978; Jöhnk et al., 2008).

\section{Results}

The Chl-a concentration in lake Trasimeno ranged from $<1$ to $130 \mathrm{mg} \mathrm{m}^{-3}$ with an annual pattern dominated by a summer bloom (Fig. 2). Focusing on a summer period from July to September in 2019, we can see that the increase in Chl-a starts in July and peaks in August and September (Fig. 3). Comparing the CCI estimates of Chl-a with that of the highfrequency WISPstation revealed a close correspondence between the two estimates, for example, both detecting a steep increase around the 12th of August. The WISPstation estimate of the concentration of phycocyanin rapidly increased around this period indicating that cyanobacteria were likely causing the increase in Chl-a concentration. Counts of cyanobacteria taxa are carried out under government regulations (Ministry of Health, 1998) and were reported by the regional authority (ARPA, Umbria; Charavgis et al., 2020) at approximately weekly intervals during bathing season. These show the underlying changes in composition and abundance of cyanobacteria during this period (Fig. 3). The cyanobacteria community was dominated by Cylindrospermopsis raciborskii during the bloom period of mid-to-late August with its increase and decline being broadly matched by estimates of Chl-a and phycocyanin.

In order to understand the factors influencing the dynamics of Chl-a in Lake Trasimeno, we first carried out a NPMR including the variables day of year (DOY), year, lake level, lake surface water temperature, wind vectors, the NAO, and the sum of the antecedent rain for 7 days (Table 1). The best model had an $x R^{2}$ of 0.62 and included DOY, year, lake level, and the NAO; however, the NAO was interchangeable with lake surface water temperature. The sensitivity value provides an indication of the importance of the variables in the models. The DOY had the highest sensitivity value $(0.338)$ followed by year $(0.065)$, lake level (0.014), and the NAO (0.004), while interchanging the latter with LSWT in a second model yielded a sensitivity of 0.006 (Table 1). Contour plots were produced to visualize estimates for Chl-a for DOY with lake level, NAO, and LSWT (Fig. 4). The contour lines and color intensity represent Chl-a in $4 \mathrm{mg} \mathrm{m}^{-3}$ increments. Common to all the plots are the higher concentrations centered around day 250 (7th September). Chl-a concentration was estimated to be higher at more positive values of the NAO, at lower lake levels and at warmer temperatures. The similar responses and tight intertwining of seasonal parameters obviously present a difficulty in either deciding on key factors or partitioning influence. We also applied Google AI AutoML to develop a model for Chl-a as a designated feature. Overall the model also had an $R^{2}$ of 0.62 and the parameters with the highest estimated percentage feature importance were date (83.3), the seven-day antecedent sum of rainfall (6.5), LSWT 


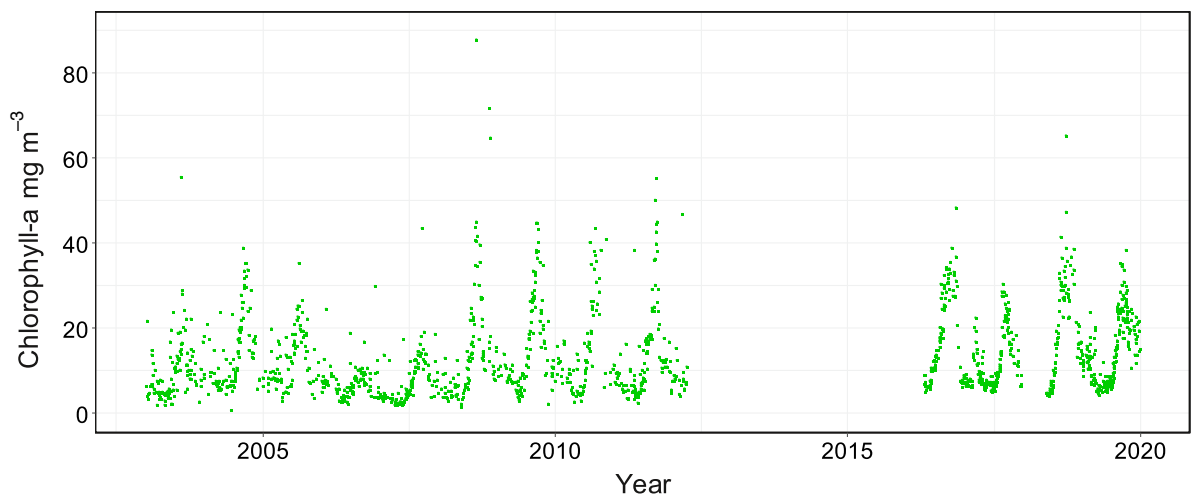

Fig. 2 Satellite-derived Chl-a in Trasimeno from 2003 to 2019. Significant data gap from 2012 to 2015 is due to the unavailability of optical satellite data with the same

(5.8), and NAO (3). While parameters estimated to have less importance included the $v$ wind component (0.8), $u$ wind component (0.6), and the lake level (0).

In order to examine the increase in temperature, we needed a long time series and used the ERA5 data to examine the increase in air temperature for Lake Trasimeno. The Theil-Sen estimate for slope for annual average temperature between 1980 and 2019 was $0.05(P \leq 0.001)$ estimating an increase from 12.7 to $14.5^{\circ} \mathrm{C}$. Similarly the increase in temperature for the summer period (June, July, August) had a slope of $0.06(P \leq 0.001)$ increasing from 22 to $24^{\circ} \mathrm{C}$. For shallow Lake Trasimeno, the LSWT was highly correlated with air temperature $\left(R^{2}=0.94\right)$ as previously found (Ludovisi \& Gaino, 2010). As the temperature is increasing and its importance in influencing blooms is evident either directly or indirectly through the significance of the seasonal component or via the NAO index, it deserves further analysis to determine if there is an influence on the phenology of phytoplankton blooms. It had been postulated that perhaps blooms might occur earlier with warmer temperatures or be of longer duration. Using $15 \mathrm{mg} \mathrm{m}^{-3}$ to define the SOS for Chl-a, we found that the timing was variable and ranged from DOY 196 (July 15, 2016) to 242 (August 30, 2007) (Fig. 5). Comparing with LSWT, the timing of the SOS (when LSWT exceeded $20^{\circ} \mathrm{C}$ ) ranged from DOY 117 (April 27, 2005) to 155 (June 4,, 2004) (Fig. 5). The SOS for temperature was not significantly correlated with the SOS for Chl-a $\left(r_{S},-0.023, P=0.95\right)$.

However, the LOS of Chl-a appeared related to the LOS of temperature which could be described by a characteristics of MERIS and OLCI sensors. One high value of $130 \mathrm{mg} \mathrm{m}^{-3}$ on the $16 / 09 / 2008$ was removed for clarity

quadratic equation $\left(R^{2}=0.92, P \leq 0.001\right.$, Fig. 6$)$. It appears that if the LOS for temperature is either too short or too long, it may constrain the LOS of Chl-a with an optimum of around 130 days (Fig. 6). The Chl-a LOS was also related to the SOS for temperature $\left(r_{S}=0.72, P=0.012\right)$ with years where $20^{\circ} \mathrm{C}$ was reached earlier like in 2005 and 2007 having a shorter Chl-a LOS (Fig. 5). A similar negative correlation $\left(r_{S}=-0.811, P \leq 0.001\right)$ was found between LSWT LOS and average Chl-a concentration (calculated for a 14-day window around DOY 250 when values are typically at a maximum).

In order to understand the implications of this, we examined a longer time series, available for air temperature, to see if there were any trends in the summer temperature phenology that could have implications for lake phytoplankton (Fig. 7).

We found evidence for an increase in the LOS $\left(R^{2}=0.28, P \leq 0.001\right)$, a decrease in $\operatorname{SOS}\left(R^{2}=0.27\right.$, $P \leq 0.001)$ but not the EOS $\left(R^{2}=0.06, P \leq 0.12\right)$ with an estimated increase in 16 days LOS over the period. To answer the question as to why earlier and longer occurrence of higher temperatures might lower the Chl-a LOS, we looked at the nutrient data from the local authority (https://apps.arpa.umbria.it/acqua/ qualita-acque-superficiali). Phosphate concentrations were occasionally below the level of detection in summer months; the concentrations for July for the last three years were 16,18 , and $<10 \mu \mathrm{g}^{-1} \mathrm{PO}_{4}-\mathrm{P}$ for 2019, 2018, and 2017, respectively. However, both the temporal resolution (bimonthly) and the spatial coverage (two stations) prevented more detailed analysis. Another potential mechanism could be that 

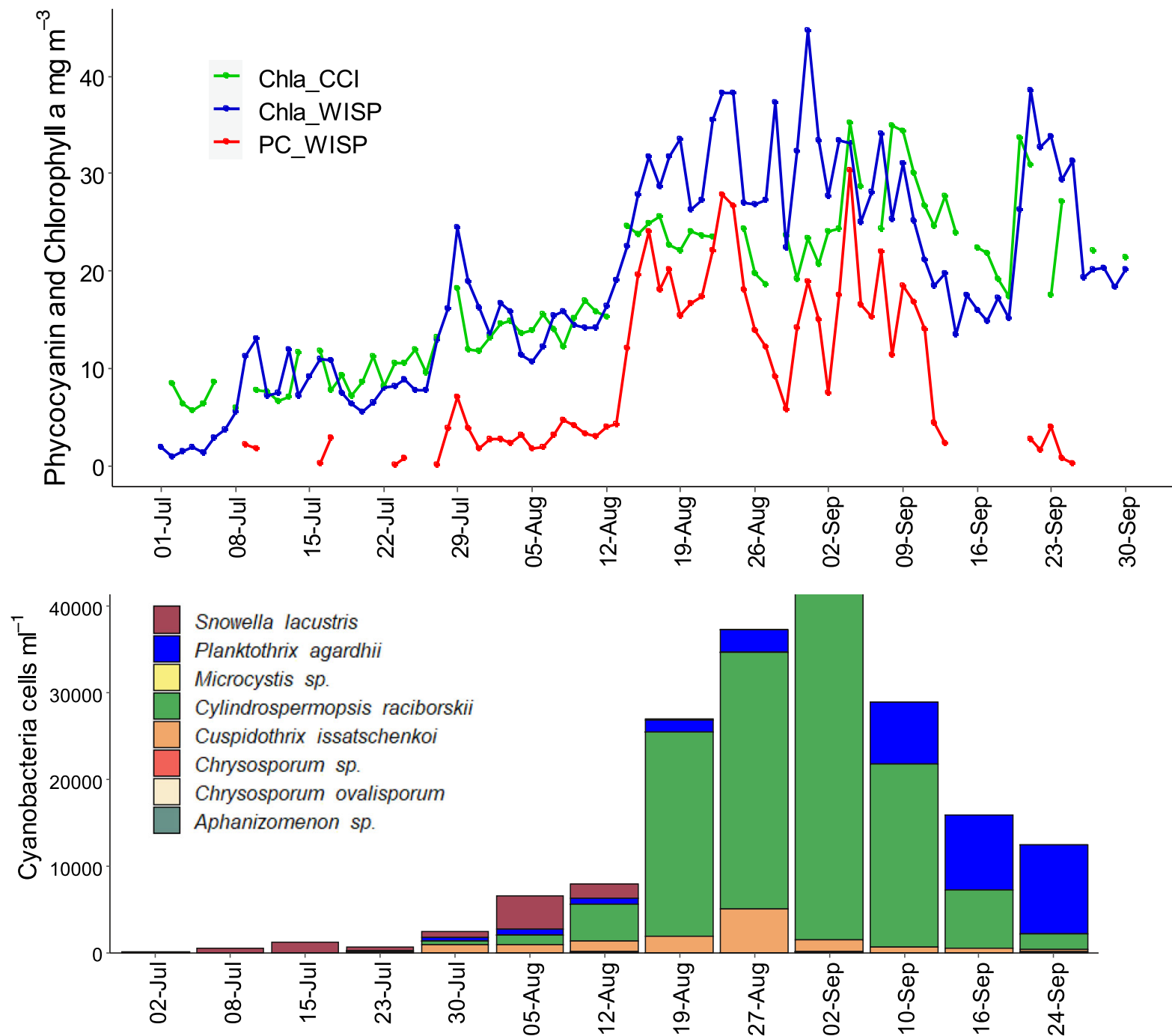

Fig. 3 (Top) estimates of Chl-a from the CCI project (Chla_CCI) and WispStation estimated Chl-a (Chla_WISP) and phycocyanin (PC_WISP) in 2019. (Bottom) counts of cyanobacteria cells per $\mathrm{ml}$ in 2019 reported by Charavgis et al.
(2020). Note continuous and discontinuous x-axis on top and bottom figures, respectively. Counts of Microcystis sp., Chrysosporum spp. and Aphanizomenon sp. were below 120 and are not visible on the graph

Table 1 Results of NPMR (nonparametric multiplicative regression) models for chlorophyll-a

\begin{tabular}{lllllllllllllll}
\hline $\mathrm{xR}^{2}$ & $\begin{array}{l}\text { Ave } \\
\text { size }\end{array}$ & $\begin{array}{l}\text { Variable } \\
1\end{array}$ & Tol. & Sen. & $\begin{array}{l}\text { Variable } \\
2\end{array}$ & Tol. & Sen. & $\begin{array}{l}\text { Variable } \\
3\end{array}$ & Tol. & Sen. & $\begin{array}{l}\text { Variable } \\
4\end{array}$ & Tol. & Sen. & $P$ \\
\hline 0.62 & 99.1 & DOY & 18.3 & 0.338 & Year & 1.2 & 0.065 & Level & 0.7 & 0.014 & NAO & 3.3 & 0.004 & 0.045 \\
0.62 & 98.7 & DOY & 18.3 & 0.331 & Year & 1.2 & 0.064 & Level & 0.6 & 0.017 & LSWT & 13.0 & 0.006 & 0.045
\end{tabular}

First model (row 1) included NAO and second model (row 2) LSWT. The second model shows that NAO was interchangeable with LSWT

$x R^{2}$ cross-validated $\mathrm{R}^{2} ;$ Ave. size Average neighborhood size; Tol. tolerance; Sen. sensitivity; NAO North Atlantic Oscillation; Level lake level; $L S W T$ lake surface water temperature 
Fig. 4 Nonparametric multiplicative regression estimates for Chlorophyll-a ( $\mathrm{mg} \mathrm{m}^{-3}$; contour lines) against DOY (day of year) for lake level (m), NAO (North Atlantic Oscillation) and lake surface water temperature $\left({ }^{\circ} \mathrm{C}\right)$
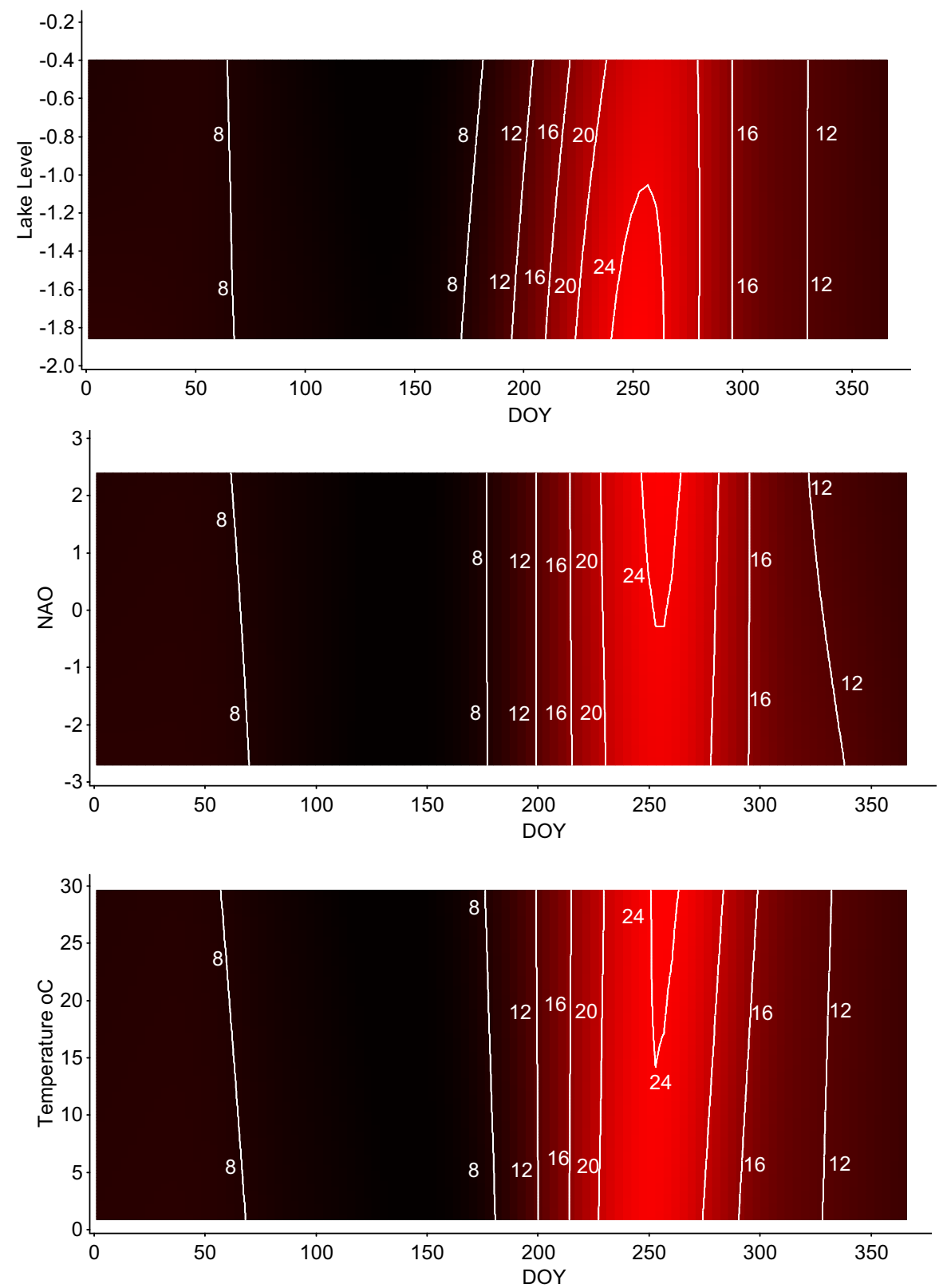

the longer period of warmer temperature could be increasing the amount of calcium carbonate precipitation which could reduce resources through the coprecipitation of phosphorus (Otsuki \& Wetzel, 1972). Using chemistry data on major ions (Ludovisi \& Gaino, 2010), we followed the recommendations of (Tang et al., 2021) in using the PHREEQC software to calculate the calcium carbonate precipitation potential (CCPP) for an open system for various temperature increments (Fig. 8). Values of CCPP increased with increasing temperature, for example, from 0.68 to $0.76 \mathrm{mmol} \mathrm{kg}^{-1}$ from 15 to $25^{\circ} \mathrm{C}$, an increase of $12 \%$.

\section{Discussion}

Examination of the satellite time series of Chl-a concentration showed that the annual pattern was dominated by a summer bloom that regularly occurred over the years examined. There was good 


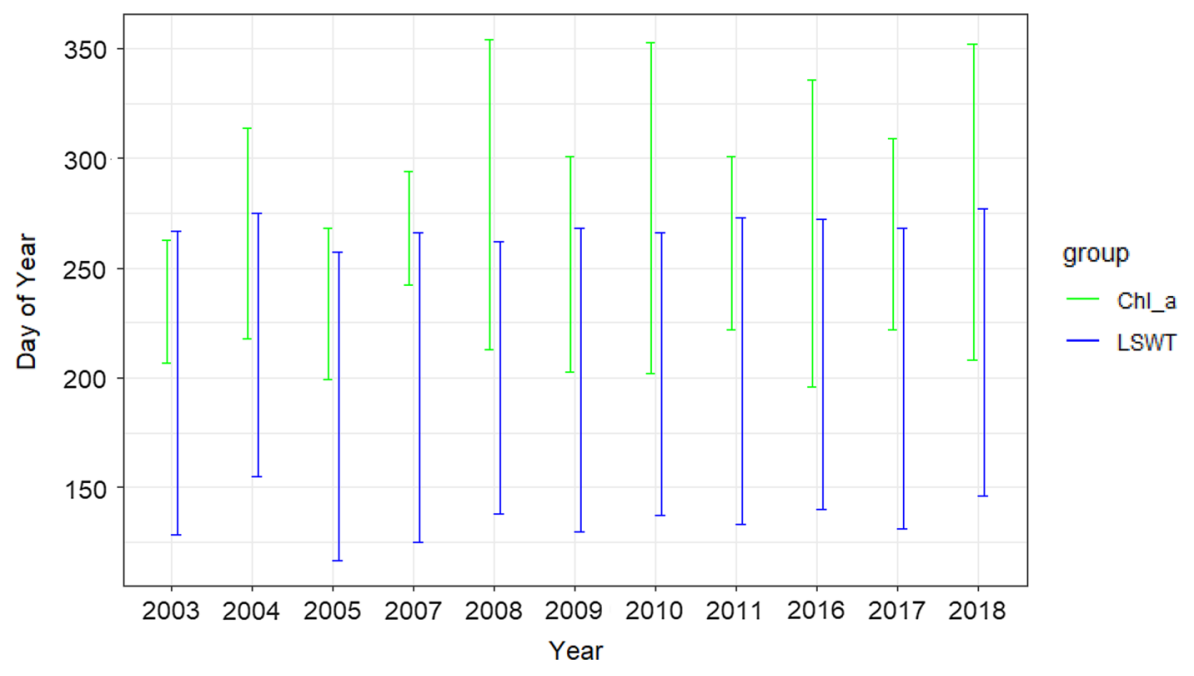

Fig. 5 Start, end, and length of season for Chl-a $\left(\geq 15 \mathrm{mg} \mathrm{m}^{3}\right)$ and lake surface water temperature (LSWT) ( $\left.\geq 20^{\circ} \mathrm{C}\right)$

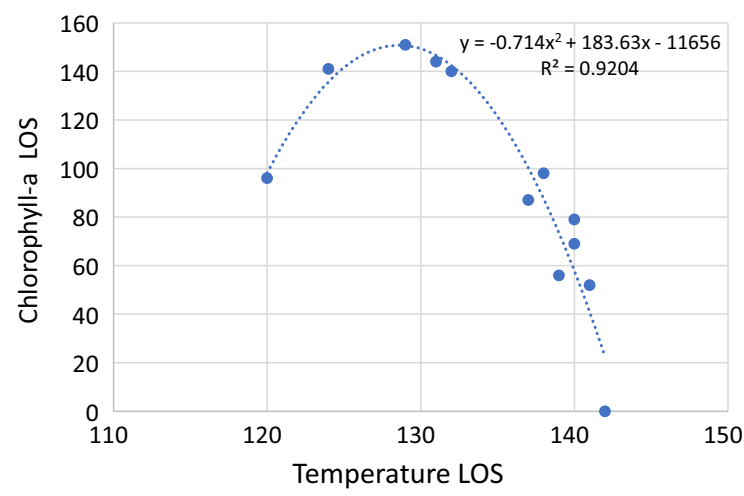

Fig. 6 Chlorophyll-a length of season (LOS) $\left(>15 \mathrm{mg} \mathrm{m}^{-3}\right)$ and temperature $\operatorname{LOS}\left(>20^{\circ} \mathrm{C}\right)$ with quadratic equation line fit

correspondence between the Chl-a estimated by the WISPstation high-frequency monitoring and that of the lakes CCI project derived from Sentinel 3 OLCI images. The increase, duration, and decline of the seasonal bloom were adequately delineated and were also substantiated by the changes in abundance and composition in cyanobacteria determined at weekly interval by the local authority (Charavgis et al., 2020). Such rapid shifts in Chl-a concentration over a period of weeks have been found before (Bresciani et al., 2018) and underline the value of high-frequency monitoring but also indicate that the data gathered by the three optical sensors, including data obtained from the lakes CCI project (Crétaux et al., 2020), perform well in detecting dynamic changes underlain by a rapidly changing phytoplankton community.
Google AI AutoML, and NPMR were used to examine the environmental parameters influencing Chl-a concentration dynamics between 2003 and 2011. Both modeling approaches found the time component to be the most important accounting for $83.3 \%$ as feature importance in Google AI while in NPMR, a sensitivity value was recorded of 0.338 and 0.065 for DOY and year, respectively. The seven-day antecedent rainfall was the next most important for the Google AI $(6.5 \%)$ while this parameter was not included in the NPMR. In NPRM, the lake water level was the next most sensitive $(0.014)$ followed by either the NAO (0.004) or temperature (0.006). These variables were also included in the Google AI AutoML $(>3 \%)$ with the exception of lake level. One of the drawbacks in the Google AI approach is the lack of interpretable diagnostic output to examine the behavior of individual parameters. For the NPMR, the contour plots indicated higher concentrations centered around day 250 ( 7 th September). Chl-a concentration was estimated to be higher at more positive values of the NAO, at lower lake levels and at warmer temperatures. It may be difficult to isolate the relative importance of these parameters. The models already incorporate the seasonal and temporal components and while the inclusion of other variables indicates that they explain additional variation, a lot of the variation may also be already explained by the seasonal component (also for other variables). However, the estimated response of Chl-a to higher summer temperatures and a more positive NAO is 

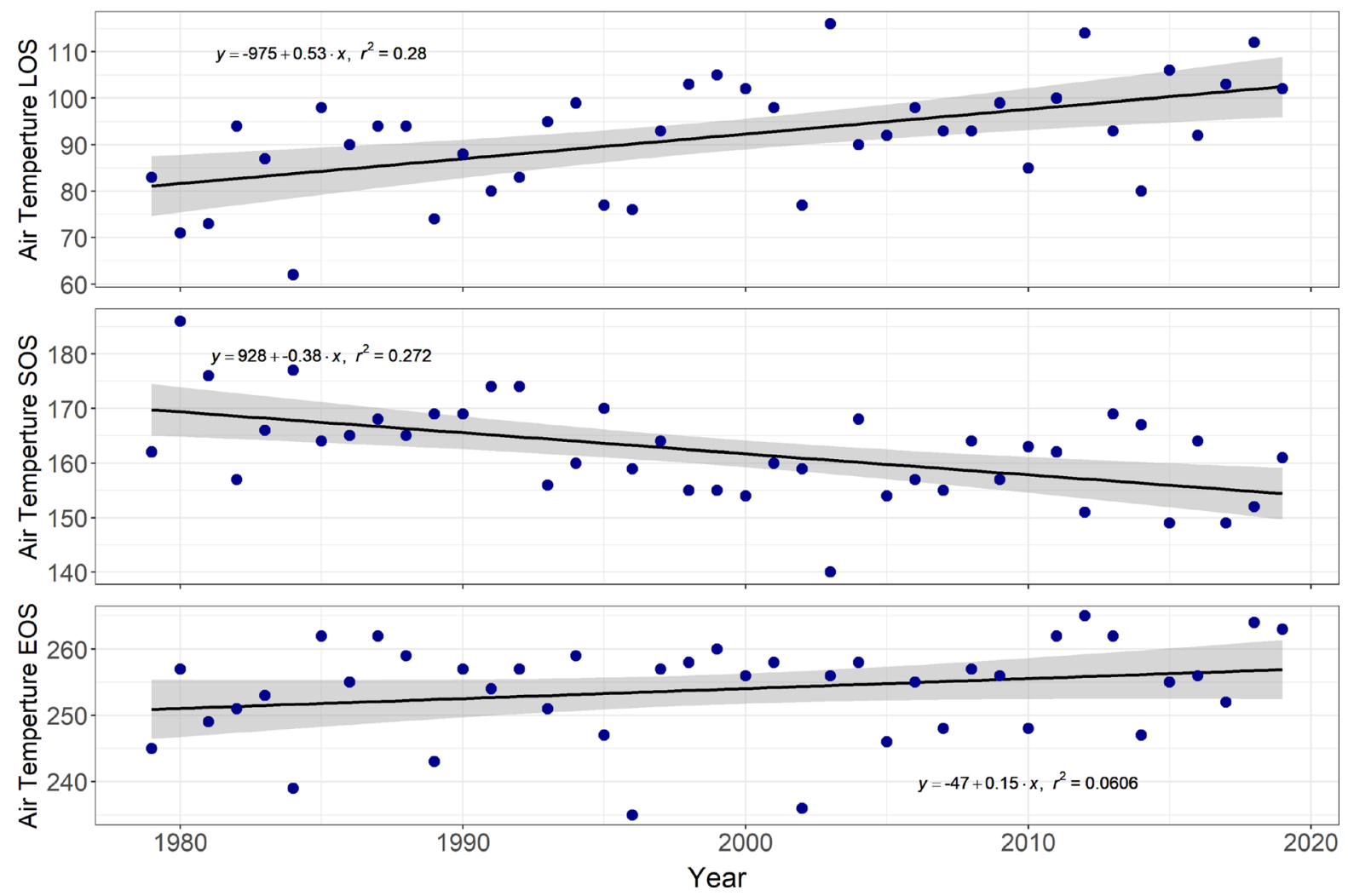

Fig. 7 Start, end, and length of season where average daily air temperature was $\geq 20^{\circ} \mathrm{C}$ in lake Trasimeno from 1979 to 2019 (SOS, EOS , and LOS, respectively)

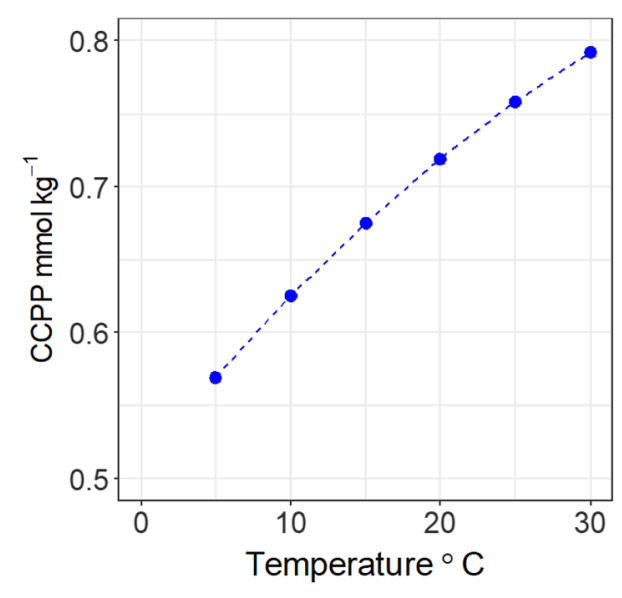

Fig. 8 Increase in the calcium carbonate precipitation potential (CCPP) with increasing temperature estimated for Lake Trasimeno

not surprising. Cyanobacteria are well known to respond to higher temperatures and a more positive NAO around this time period reflects high pressure with warm sunny weather (Konopka \& Brock, 1978;
Criado-Aldeanueva \& Soto-Navarro, 2020). The incorporation of indices such as the NAO likely reflects the importance of other parameters associated with summer heatwaves such as low cloud cover, reduced wind speed, as well as higher temperatures that promote cyanobacteria growth directly or indirectly through water column stability (Jöhnk et al., 2008). The positive influence of lower lake levels may reflect increased suspension of sediments by wave action potentially increasing nutrient levels and promoting bloom development (Søndergaard et al., 2003; Ludovisi \& Gaino, 2010). In addition, lower lake levels can be associated with higher phytoplankton biomass in shallow lakes through increasing light availability alone (Nõges et al., 2003). While the seven-day antecedent sum of rainfall was not included in NPMR, its inclusion in Google AI may reflect the importance of inflow events transporting nutrients to the lake from the catchment. Some visual evidence of the importance of this in bloom development has been seen in satellite images in 2018 for Lake Trasimeno 
(Bresciani et al., 2020). However, significant storm events and flushing can suppress blooms in shallow lakes (Havens et al., 2019).

The examination of the phytoplankton phenology found that there was no evidence for an earlier increase in summer blooms that was related to the earlier onset of higher temperatures. It was also anticipated that a longer warmer period with temperatures above $20^{\circ} \mathrm{C}$ would lead to a longer bloom period but the relationship was more complex. Contrary to expectations, an earlier onset and longer duration of warmer temperatures appeared to be related to a shorter phytoplankton bloom. The relationship could be described by a quadratic equation where initially Chl-a increased with a longer LOS for temperature but started to decline after 130 days. The relationship likely reflects aspects of resource availability. The decline after 130 days could be the result of a longer LOS, typically with an earlier SOS, leading to more or earlier uptake of nutrients resulting in lower amounts to support later bloom development or duration. A significant proportion of the phytoplankton biomass was found to be comprised of chlorophytes in early summer (Havens et al., 2009) and these could play a role in reducing resources for other succession species. While the frequency of chemical monitoring did not allow incorporation into analysis, phosphate concentrations were occasionally below the limit of detection $\left(<10 \mu \mathrm{g} \mathrm{l}^{-1} \mathrm{PO}_{4}-\mathrm{P}\right)$ and monitoring was not carried out for the month of August which may be the critical period for bloom development. However, for at least some years, phosphate is likely to limit bloom development and overall, there is a close relationship between total phosphorus and summer Chl-a $\left(R^{2}=0.65\right)$ (Bresciani et al., 2021, in press). During the 2003 heatwave in Europe, examples were recorded of very large cyanobacteria blooms but this was under hypertrophic conditions (Jöhnk et al., 2008). Similarly, in shallow lake Taihu in China, high total phosphorus concentrations $\left(>130 \mu \mathrm{g}^{-1}\right)$ have led to extensive blooms, despite restoration attempts (Qin et al., 2019, 2021). In addition, earlier onset of Microcystis blooms has been found to be dependent on sufficient nutrient concentrations (Deng et al., 2014). Furthermore, the fact that SOS can vary spatially within a lake underlines the importance of other local factors such as nutrients in addition to climate warming (Shi et al., 2019). An interplay during summer between nutrient availability and the increasingly more optimal climatic conditions (temperature, water column stability, cloud cover) for cyanobacteria is to be expected in lakes that are not nutrient rich. This may cover the majority of monitored lakes in Europe as only $16 \%$ had phosphorus conditions classified as less than good (although 36\% were not classified) (Kristensen et al., 2018).

The potential for warmer temperatures to increase the rate of calcite precipitation was also examined, and an increase from 15 to $25^{\circ} \mathrm{C}$ estimated an increase of $12 \%$ in the calcium carbonate precipitation potential (CCPP). This may lead to more coprecipitation of phosphorus leading to smaller blooms, especially considering the longer period of warmer weather, and also the fact that $\mathrm{pH}$ may be higher with increased photosynthesis (Otsuki \& Wetzel, 1972; Homa \& Chapra, 2011). It may be possible to examine the presence and extent of this process in future as methods have recently been developed to use remote sensing to detect calcite spatially in lakes (Heine et al., 2017).

A more systematic examination of the response of Chl-a concentrations to climate change in summer is needed. While the increasingly more optimal conditions for cyanobacteria has been predicted to lead to an increase in frequency and abundance of blooms, it may also be plausible that higher temperatures for longer periods may alter the phenology of many limnetic organisms and catchment processes, altering nutrient and other geochemical cycles and resulting in unanticipated responses in summer phytoplankton, including blooms of shorter duration. There may be a tendency for publications to confirm the former anticipated response (Simundic, 2013). Given the increase in LOS observed using the ERA air temperature data since 1980, climate change may continue to alter the phenology of the phytoplankton, even if larger or more prolonged blooms are not expected, this can lead to asynchronization with other groups such as zooplankton thereby altering energy transfer between trophic levels (Winder \& Sommer, 2012). The lakes CCI database may be suited to exploring the incidence of such patterns as it contains information on lake level, temperature, Chl-a, turbidity, lake area, and ice cover and is due to expand to about 2000 lakes in 2021 (https://climate.esa.int/en/projects/lakes/). One of the limitations of the current dataset used here is the presence of gaps-especially between 2012 and 2015. One potential solution would be to use data from the 
MODIS satellite which has been used successfully to define bloom phenology previously in Lake Taihu in China (Shi et al., 2017, 2019). This solution is currently being evaluated for incorporation into later versions of the lakes CCI database, but would have to be evaluated for lake Trasimeno. Lake Trasimeno may have provided us with a 'tidy' example in that there is essentially one well-timed and well-defined Chl-a peak per year and innovative ways may be needed for more widespread application of this approach to lakes with more complex phytoplankton dynamics.

\section{Conclusions}

Lake Trasimeno has a well-defined summer bloom of phytoplankton and its seasonal timing could be described using satellite data dating back to 2003 . Larger summer blooms were associated with warmer temperatures, a lower lake level and a more positive NAO, indicative of high pressure and warm sunny calm weather. The relative role of these parameters and other factors in influencing Chl-a is difficult to apportion because they are correlated seasonally. Interestingly, blooms were not occurring earlier but the length of season where water temperatures were above $20^{\circ} \mathrm{C}$ appeared to play a role in controlling the duration of blooms. A longer warmer season, typically commencing earlier in the year, was found to lead to a shorter duration of blooms likely owing to seasonal nutrient limitation and perhaps increased calcite precipitation. As the duration of warmer temperatures is increasing, this is likely to be more important in future with implications for species phenology and lake ecosystem functioning.

Acknowledgements We would like to thank the "Cooperativa dei Pescatori del Trasimeno" for the support in field campaigns. Many thanks to Luca Nicoletti and Luca Galli from Polvese Center "Climate Change and Biodiversity in Lakes and Wetlands" from ARPA Umbria for collecting water samples. We also thank the Province of Perugia for the availability to use the platform in Polvese Island. We would like to acknowledge the two anonymous reviewers for valuable comments and suggestions that helped improve this study.

Funding This research is part of the ESA CCI LAKES project (Contract No. 40000125030/18/I-NB) and of the H2020 projects Water-ForCE (GA No. 101004186) and EOMORES (GA No. 730066).
Data availability All CCI and ERA data are available online as cited.

Code availability Not applicable.

\section{Declarations}

Conflict of interest The authors declare that they have no conflict of interest.

\section{Ethical approval Not applicable.}

Consent to participate All authors have agreed to participate.

Consent for publication All authors have read and agreed to this version of the manuscript.

Open Access This article is licensed under a Creative Commons Attribution 4.0 International License, which permits use, sharing, adaptation, distribution and reproduction in any medium or format, as long as you give appropriate credit to the original author(s) and the source, provide a link to the Creative Commons licence, and indicate if changes were made. The images or other third party material in this article are included in the article's Creative Commons licence, unless indicated otherwise in a credit line to the material. If material is not included in the article's Creative Commons licence and your intended use is not permitted by statutory regulation or exceeds the permitted use, you will need to obtain permission directly from the copyright holder. To view a copy of this licence, visit http://creativecommons.org/licenses/by/4.0/.

\section{References}

Bresciani, M., I. Cazzaniga, M. Austoni, T. Sforzi, F. Buzzi, G. Morabito \& C. Giardino, 2018. Mapping phytoplankton blooms in deep subalpine lakes from Sentinel-2A and Landsat-8. Hydrobiologia 824: 197-214.

Bresciani, M., G. Free, M. Pinardi, M. Laanen, R. Padula, A. Fabbretto, S. Mangano, \& C. Giardino, 2021. Optical remote sensing in shallow lake Trasimeno: understanding from applications across diverse temporal, spectral and spatial scales Springer "Water" book series.

Bresciani, M., M. Pinardi, G. Free, G. Luciani, S. Ghebrehiwot, M. Laanen, S. Peters, V. Della Bella, R. Padula \& C. Giardino, 2020. The use of multisource optical sensors to study phytoplankton spatio-temporal variation in a shallow turbid lake. Water 12: 284.

Carslaw, D. C. \& K. Ropkins, 2012. Openair-an R package for air quality data analysis. Environmental Modelling \& Software 27: 52-61.

Carvalho, L., E. B. Mackay, A. C. Cardoso, A. Baattrup-Pedersen, S. Birk, K. L. Blackstock, G. Borics, A. Borja, C. K. Feld \& M. T. Ferreira, 2019. Protecting and restoring Europe's waters: an analysis of the future development needs of the Water Framework Directive. Science of the Total Environment 658: 1228-1238. 
Charavgis, F., A. Cingolani, M. Di Brizio, E. Rinaldi, G. Tozzi, \& P. Stranieri, 2020. Qualita' delle acque di balneazione dei laghi Umbri, stagione balneare 2019. ARPA, Umbria.

Cingolani, A., \& F. Charavgis, 2017. Valutazione dello stato ecologico e chimico dei corpi idrici lacustri (2013-2015). ARPA, Umbria, Italy: 25.

Cingolani, A., \& F. Charavgis, 2018. Valutazione dello stato ecologico e chimico dei corpi idrici lacustri (2015-2017). ARPA, Umbria, Italy: 26.

Codd, G. A., L. F. Morrison \& J. S. Metcalf, 2005. Cyanobacterial toxins: risk management for health protection. Toxicology and Applied Pharmacology 203: 264-272.

Council of the European Communities, 2000. Directive 2000/60/EC of the European Parliament and of the Council of 23 October 2000 establishing a framework for community action in the field of water policy. L327: 72.

Council of the European Communities, 2013. Commission Decision of 20 September 2013 establishing pursuant to Directive 2000/60/EC of the European Parliament and of the Council, the values of the Member State monitoring system classifications as a result of the intercalibration exercise and repealing Decision 2008/915/EC. Official Journal of the European Communities 480: 1-47.

Crétaux, J.-F., C. J. Merchant, C. Duguay, S. Simis, B. Calmettes, M. Bergé-Nguyen, Y. Wu, D. Zhang, L. Carrea, X. Liu, N. Selmes, \& M. Warren, 2020. ESA Lakes Climate Change Initiative (Lakes_cci): Lake products, Version 1.0. Centre for Environmental Data Analysis (CEDA), https:// catalogue.ceda.ac.uk/uuid/ 3c324bb4ee394d0d876fe2e1db217378.

Criado-Aldeanueva, F. \& J. Soto-Navarro, 2020. Climatic indices over the Mediterranean sea: a review. Applied Sciences Multidisciplinary Digital Publishing Institute 10: 5790.

Deng, J., B. Qin, H. W. Paerl, Y. Zhang, J. Ma \& Y. Chen, 2014. Earlier and warmer springs increase cyanobacterial $(\mathrm{Mi}$ crocystis spp.) blooms in subtropical Lake Taihu, China. Freshwater Biology 59: 1076-1085.

DM, 2010. Ambiente 8 Novembre 2010, N.260. "Regolamento recante i criteri tecnici per la classificazione dello stato dei corpi idrici superficiali, per la modifica delle norme tecniche del decreto legislativo 3 aprile 2006, n. 152, recante norme in materia ambientale, predisposto ai sensi dell'articolo 75, comma 3, del medesimo decreto legislativo". S.O. n. 31 alla GU 7 febbraio 2011 n. 30.

Dragoni, W., 2004. Il Lago Trasimeno e le variazioni climatiche. Provincia di Perugia, Perugia, Italy.

Ellis, C. J., B. J. Coppins, T. P. Dawson \& M. R. Seaward, 2007. Response of British lichens to climate change scenarios: trends and uncertainties in the projected impact for contrasting biogeographic groups. Biological Conservation 140: 217-235.

Ezra, A. G. \& D. I. Nwankwo, 2001. Composition of phytoplankton algae in Gubi reservoir, Bauchi, Nigeria. Journal of Aquatic Sciences 16: 115-118.

Forkel, M., N. Carvalhais, J. Verbesselt, M. D. Mahecha, C. S. R. Neigh \& M. Reichstein, 2013. Trend change detection in NDVI time series: effects of inter-annual variability and methodology. Remote Sensing 5: 2113-2144.

Forkel, M., M. Migliavacca, K. Thonicke, M. Reichstein, S. Schaphoff, U. Weber \& N. Carvalhais, 2015. Codominant water control on global interannual variability and trends in land surface phenology and greenness. Global Change Biology 21: 3414-3435.

Forkel, M., \& T. Wutzler, 2015. greenbrown - land surface phenology and trend analysis. A package for the R software. Max Planck Institute, Germany, http://greenbrown.rforge.r-project.org/.

Free, G., M. Bresciani, M. Pinardi, N. Ghirardi, G. Luciani, R. Caroni \& C. Giardino, 2021a. Detecting climate driven changes in chlorophyll-a in deep subalpine lakes using long term satellite data. Water 13: 866.

Free, G., M. Bresciani, M. Pinardi, C. Giardino, K. Alikas, K. Kangro, E.-I. Rõõm, D. Vaičiūtè, M. Bučas, E. Tiškus, A. Hommersom, M. Laanen, \& S. Peters, 2021b. Detecting climate driven changes in chlorophyll-a using high frequency monitoring: the impact of the 2019 European Heatwave in Three Contrasting Aquatic Systems. Sensors 21

Free, G., M. Bresciani, W. Trodd, D. Tierney, S. O'Boyle, C. Plant \& J. Deakin, 2020. Estimation of lake ecological quality from Sentinel-2 remote sensing imagery. Hydrobiologia 847: 1423-1438.

Frondini, F., W. Dragoni, N. Morgantini, M. Donnini, C. Cardellini, S. Caliro, M. Melillo \& G. Chiodini, 2019. An endorheic lake in a changing climate: geochemical investigations at lake Trasimeno (Italy). Water Multidisciplinary Digital Publishing Institute 11: 1319.

García, M. A., H. Moutahir, G. M. Casady, S. Bautista \& F. Rodríguez, 2019. Using hidden Markov models for land surface phenology: an evaluation across a range of land cover types in southeast Spain. Remote Sensing 11: 507.

Giardino, C., M. Bresciani, P. Villa \& A. Martinelli, 2010. Application of remote sensing in water resource management: the case study of lake Trasimeno, Italy. Water Resources Management 24: 3885-3899.

Gons, H. J., 1999. Optical teledetection of chlorophyll a in turbid inland waters. Environmental Science \& Technology 33: 1127-1132.

Havens, K. E., A. C. Elia, M. I. Taticchi \& R. S. Fulton, 2009. Zooplankton-phytoplankton relationships in shallow subtropical versus temperate lakes Apopka (Florida, USA) and Trasimeno (Umbria, Italy). Hydrobiologia 628: 165-175.

Havens, K. E., G. Ji, J. R. Beaver, R. S. Fulton \& C. E. Teacher, 2019. Dynamics of cyanobacteria blooms are linked to the hydrology of shallow Florida lakes and provide insight into possible impacts of climate change. Hydrobiologia 829: 43-59.

Heine, I., A. Brauer, B. Heim, S. Itzerott, P. Kasprzak, U. Kienel \& B. Kleinschmit, 2017. Monitoring of calcite precipitation in hardwater lakes with multi-spectral remote sensing archives. Water 9: 15.

Ho, J. C., A. M. Michalak \& N. Pahlevan, 2019. Widespread global increase in intense lake phytoplankton blooms since the 1980s. Nature 574: 667-670.

Homa, E. S. \& S. C. Chapra, 2011. Modeling the impacts of calcite precipitation on the epilimnion of an ultraoligotrophic, hard-water lake. Ecological Modelling 222: 76-90.

Huang, C., Y. Zhang, T. Huang, H. Yang, Y. Li, Z. Zhang, M. $\mathrm{He}, \mathrm{Z}$. Hu, T. Song \& A. Zhu, 2019. Long-term variation of phytoplankton biomass and physiology in Taihu lake as 
observed via MODIS satellite. Water Research 153: 187-199.

Huisman, J., G. A. Codd, H. W. Paerl, B. W. Ibelings, J. M. H. Verspagen \& P. M. Visser, 2018. Cyanobacterial blooms. Nature Reviews Microbiology 16: 471-483.

Janssen, A. B. G., S. Hilt, S. Kosten, J. J. M. de Klein, H. W. Paerl \& D. B. V. de Waal, 2021. Shifting states, shifting services: linking regime shifts to changes in ecosystem services of shallow lakes. Freshwater Biology 66: 1-12.

Jöhnk, K. D., J. Huisman, J. Sharples, B. Sommeijer, P. M. Visser \& J. M. Stroom, 2008. Summer heatwaves promote blooms of harmful cyanobacteria. Global Change Biology 14: 495-512.

Jørgensen, S. E., S. Bastianoni, F. Müller, B. C. Patten, B. D. Fath, J. C. Marques, S. N. Nielsen, E. Tiezzi \& R. E. Ulanowicz, 2007. 9 - Ecosystem principles have applications. In Jørgensen, S. E., S. Bastianoni, F. Müller, B. C. Patten, B. D. Fath, J. C. Marques, S. N. Nielsen, E. Tiezzi \& R. E. Ulanowicz (eds), A New Ecology Elsevier, Amsterdam: 199-241.

Konopka, A. \& T. D. Brock, 1978. Effect of temperature on blue-green algae (cyanobacteria) in lake Mendota. Applied and Environmental Microbiology 36: 572.

Kristensen, P., C. Whalley, F. N. N. Zal, \& T. Christiansen, 2018. European waters assessment of status and pressures 2018. EEA Report European Environment Agency.

Ludovisi, A. \& E. Gaino, 2010. Meteorological and water quality changes in Lake Trasimeno (Umbria, Italy) during the last fifty years. Journal of Limnology 69: 174-188.

Ma, X., Y. Wang, S. Feng \& S. Wang, 2015. Vertical migration patterns of different phytoplankton species during a summer bloom in Dianchi Lake, China. Environmental Earth Sciences 74: 3805-3814.

Maeda, E. E., F. Lisboa, L. Kaikkonen, K. Kallio, S. Koponen, V. Brotas \& S. Kuikka, 2019. Temporal patterns of phytoplankton phenology across high latitude lakes unveiled by long-term time series of satellite data. Remote Sensing of Environment 221: 609-620.

McCune, B., 2006. Nonparametric Multiplicative Regression for Habitat Modeling, Oregon State University, Oregon:

McCune, B., \& M. J. Mefford, 2009. HyperNiche. Nonparametric Multiplicative Habitat Modeling. MjM Software, Oregon, U.S.A.

Ministry of Health, 1998. Circolare del ministero della sanità del 09 aprile 1998, N. 400.4/13.1/3/562. Aggiornamento delle metodiche analitiche per la determinazione dei parametri previsti nel decreto interministeriale 17 giugno 1988 concernente i criteri per la definizione del programma di sorveglianza di cui all' art. 1 del D.L.14 maggio 1988 n. 155 convertito con legge del 15 luglio 1988 n. 271, 9 pp.

Nicolaou, N. \& T. G. Constandinou, 2016. A nonlinear causality estimator based on non-parametric multiplicative regression. Frontiers in Neuroinformatics 10: 19.

Nõges, T., P. Nõges \& R. Laugaste, 2003. Water level as the mediator between climate change and phytoplankton composition in a large shallow temperate lake. Hydrobiologia 506: 257-263.

OECD, 1982. Eutrophication of waters. Monitoring, assessment and control. Final report, OECD cooperative programme on monitoring of inland waters (eutrophication control).
Organisation for Economic Co-operation and Development, Paris.

O’Neil, J. M., T. W. Davis, M. A. Burford \& C. J. Gobler, 2012. The rise of harmful cyanobacteria blooms: the potential roles of eutrophication and climate change. Harmful Algae 14: 313-334.

O'Reilly, C. M., S. Sharma, D. K. Gray, S. E. Hampton, J. S. Read, R. J. Rowley, P. Schneider, J. D. Lenters, P. B. McIntyre, B. M. Kraemer, G. A. Weyhenmeyer, D. Straile, B. Dong, R. Adrian, M. G. Allan, O. Anneville, L. Arvola, J. Austin, J. L. Bailey, J. S. Baron, J. D. Brookes, E. de Eyto, M. T. Dokulil, D. P. Hamilton, K. Havens, A. L. Hetherington, S. N. Higgins, S. Hook, L. R. Izmesteva, K. D. Joehnk, K. Kangur, P. Kasprzak, M. Kumagai, E. Kuusisto, G. Leshkevich, D. M. Livingstone, S. MacIntyre, L. May, J. M. Melack, D. C. Mueller-Navarra, M. Naumenko, P. Noges, T. Noges, R. P. North, P.-D. Plisnier, A. Rigosi, A. Rimmer, M. Rogora, L. G. Rudstam, J. A. Rusak, N. Salmaso, N. R. Samal, D. E. Schindler, S. G. Schladow, M. Schmid, S. R. Schmidt, E. Silow, M. E. Soylu, K. Teubner, P. Verburg, A. Voutilainen, A. Watkinson, C. E. Williamson \& G. Zhang, 2015. Rapid and highly variable warming of lake surface waters around the globe. Geophysical Research Letters 42: 10773-10781.

Otsuki, A. \& R. G. Wetzel, 1972. Coprecipitation of phosphate with carbonates in a Marl lake. Limnology and Oceanography $17:$ 763-767.

Paerl, H. W. \& J. Huisman, 2009. Climate change: a catalyst for global expansion of harmful cyanobacterial blooms. Environmental Microbiology Reports 1: 27-37.

Palmer, S. C. J., P. D. Hunter, T. Lankester, S. Hubbard, E. Spyrakos, A. N. Tyler, M. Présing, H. Horváth, A. Lamb, H. Balzter \& V. R. Tóth, 2015. Validation of Envisat MERIS algorithms for chlorophyll retrieval in a large, turbid and optically-complex shallow lake. Remote Sensing of Environment 157: 158-169.

Peters, S., M. Laanen, P. Groetsch, S. Ghezehegn, K. Poser, A. Hommersom, E. De Reus, \& L. Spaias, 2018. WISPstation: a new autonomous above water radiometer system. Ocean Optics XXIV conference. Dubrovnik, Croatia. Available online: https://doi.org/10.5281/zenodo.2533079. Accessed 1 July 2020.

Phillips, G., A. Lyche-Solheim, B. Skjelbred, U. Mischke, S. Drakare, G. Free, M. Järvinen, C. de Hoyos, G. Morabito, S. Poikane \& L. Carvalho, 2013. A phytoplankton trophic index to assess the status of lakes for the Water Framework Directive. Hydrobiologia 704: 75-95.

Qin, B., J. Deng, K. Shi, J. Wang, J. Brookes, J. Zhou, Y. Zhang, G. Zhu, H. W. Paerl \& L. Wu, 2021. Extreme climate anomalies enhancing cyanobacterial blooms in eutrophic lake Taihu, China. Water Resources Research 57: e2020WR029371.

Qin, B., H. W. Paerl, J. D. Brookes, J. Liu, E. Jeppesen, G. Zhu, Y. Zhang, H. Xu, K. Shi \& J. Deng, 2019. Why Lake Taihu continues to be plagued with cyanobacterial blooms through 10 years (2007-2017) efforts. Science Bulletin 64: 1.

R Core Team, 2019. R: A Language and Environment for Statistical Computing. R Foundation for Statistical Computing, Vienna, Austria, https://www.R-project.org/. 
Raymond, J. E. G., 1983. Plankton and Productivity in the Oceans Zooplankton, Pergamon Press, Oxford:

Reynolds, C. S., 2006. Ecology of Phytoplankton, Cambridge University Press, Cambridge:

Rogora, M., F. Buzzi, C. Dresti, B. Leoni, F. Lepori, R. Mosello, M. Patelli \& N. Salmaso, 2018. Climatic effects on vertical mixing and deep-water oxygen content in the subalpine lakes in Italy. Hydrobiologia 824: 33-50.

Sala, O. E., F. Stuart Chapin, J. J. Armesto, E. Berlow, J. Bloomfield, R. Dirzo, E. Huber-Sanwald, L. F. Huenneke, R. B. Jackson, A. Kinzig, R. Leemans, D. M. Lodge, H. A. Mooney, M. Oesterheld, N. L. Poff, M. T. Sykes, B. H. Walker, M. Walker \& D. H. Wall, 2000. Global biodiversity scenarios for the year 2100. Science 287: 1770 .

Salmaso, N., A. Boscaini, C. Capelli, \& L. Cerasino, 2018. Ongoing ecological shifts in a large lake are driven by climate change and eutrophication: evidences from a threedecade study in Lake Garda. Hydrobiologia 824: 177-195.

Scheffer, M., 1989. Alternative stable states in eutrophic, shallow freshwater systems: a minimal model. Hydrobiological Bulletin 23: 73-83.

Scheffer, M. \& E. H. van Nes, 2007. Shallow lakes theory revisited: various alternative regimes driven by climate, nutrients, depth and lake size. In Gulati, R. D., E. Lammens, N. De Pauw \& E. Van Donk (eds), Shallow Lakes in a Changing World Springer, Dordrecht: 455-466.

Shi, K., Y. Zhang, Y. Zhang, N. Li, B. Qin, G. Zhu \& Y. Zhou, 2019. Phenology of phytoplankton blooms in a trophic lake observed from long-term MODIS data. Environmental Science \& Technology American Chemical Society 53: 2324-2331.

Shi, K., Y. Zhang, Y. Zhou, X. Liu, G. Zhu, B. Qin \& G. Gao, 2017. Long-term MODIS observations of cyanobacterial dynamics in Lake Taihu: responses to nutrient enrichment and meteorological factors. Scientific Reports 7: 40326.

Simis, S. G. H., 2006. Blue-green catastrophe: remote sensing of mass viral lysis of cyanobacteria. Ph.D. Thesis, Vrije University.

Simis, S., N. Selmes, B. Calmettes, C. Duguay, C. J. Merchant, E. Malnes, H. Yésou, \& P. Blanco, 2020. ESA Lakes
Climate Change Initiative (Lakes_cci): Product User Guide. European Space Agency, https://climate.esa.int/ documents/360/CCI-LAKES-0029-PUG_v1.1_signed_ CA.pdf.

Simundic, A.-M., 2013. Bias in research. Biochemia Medica Medicinska Naklada 23: 12-15.

Søndergaard, M., J. P. Jensen \& E. Jeppesen, 2003. Role of sediment and internal loading of phosphorus in shallow lakes. Hydrobiologia 506: 135-145.

Tang, C., B. Godskesen, H. Aktor, M. van Rijn, J. B. Kristensen, P. S. Rosshaug, H.-J. Albrechtsen \& M. Rygaard, 2021. Procedure for calculating the calcium carbonate precipitation potential (CCPP) in drinking water supply: importance of temperature. Ionic Species and Open/closed System. Water 13: 42.

Touchette, B. W., J. M. Burkholder, E. H. Allen, J. L. Alexander, C. A. Kinder, C. Brownie, J. James \& C. H. Britton, 2007. Eutrophication and cyanobacteria blooms in run-ofriver impoundments in North Carolina, U.S.A. Lake and Reservoir Management 23: 179-192.

Tyler, A. N., P. D. Hunter, E. Spyrakos, S. Groom, A. M. Constantinescu \& J. Kitchen, 2016. Developments in Earth observation for the assessment and monitoring of inland, transitional, coastal and shelf-sea waters. Science of the Total Environment 572: 1307-1321.

Velleman, P. F., 1989. Data Desk: Handbook, Volume 1 (1), Data Description, Inc., New York:

Winder, M. \& U. Sommer, 2012. Phytoplankton response to a changing climate. Hydrobiologia 698: 5-16.

Woolway, R. I., E. Jennings, T. Shatwell, M. Golub, D. C. Pierson \& S. C. Maberly, 2021. Lake heatwaves under climate change. Nature 589: 402-407.

Yost, A. C., 2008. Probabilistic modeling and mapping of plant indicator species in a Northeast Oregon industrial forest, USA. Ecological Indicators 8: 46-56.

Publisher's Note Springer Nature remains neutral with regard to jurisdictional claims in published maps and institutional affiliations. 